\title{
Media Sosial Sebagai Sebuah Ruang Hiperealitas
}

\author{
Studi kasus pada twitter
}

\author{
Elly Komala \\ Universitas Pasundan \\ Email: elly.komala@unpas.ac.id
}

\begin{abstract}
ABSTRAK
Penelitian ini berjudul "Media sosial sebagai sebuah ruang hiperealitas; studi kasus pada Twitter”. Zaman modern ini internet sudah dianggap menjadi wadah berkunjung bagi masyarakat yang melek teknologi. Kebutuhan yang disediakan dalam internet mencakup berbagai varian dengan situs kunjungan yang berbeda. Serangkaian proses menempatkan sistem maya sebagai wadah penghubung dengan situs-situs sebagai perantaranya.

Teori yang digunakan adalah teori Simulasi/ Hiperealitas. Metode penelitian yang digunakan adalah metode penelitian kualitatif. Teknik pengumpulan data dilakukan melalui studi kepustakaan, observasi partisipan, dan wawancara dengan 3 orang informan.

Berdasarkan hasil penelitian, wawancara dan analisis yang telah peneliti lakukan mengenai media sosial sebagai sebuah ruang hiperalitas, maka dapat ditarik beberapa kesimpulan yakni media social Twitter telah memenuhi unsur-unsur sebagai sebuah ruang hiperealitas menurut teori hiperealitas Baudrilard.
\end{abstract}

Kata kunci: hiperealitas, twitter, smartuser.

\section{Pendahuluan}

Internet berkembang

seiring dengan perkembangan teknologi di berbagai belahan dunia, terutama di Indonesia. Internet memiliki konsep mengkoneksikan para pengguna (user) dalam sistem jaringan, dimana semua dapat mengakses dalam satu sistem pengoperasian tertentu. Zaman modern ini internet sudah dianggap menjadi wadah berkunjung bagi masyarakat yang melek teknologi. Kebutuhan yang disediakan dalam internet mencakup berbagai varian dengan situs kunjungan yang berbeda. Serangkaian proses menempatkan sistem maya sebagai wadah penghubung dengan situs-situs sebagai perantaranya.

Internet memiliki sebuah konsep yang praktis dan kompleks karena memusatkan segala aktifitas situs dalam satu wadah. Seperti contohnya sebuah rumah tangga yang terdiri dari ayah, ibu dan anak mempunyai fasislitas internet di rumahnya tentunya mempunyai kebutuhan dan keinginan yang berbeda. Internet dapat mengakomodir kebutuhan mereka dimana sang ayah dapat mengakses pekerjaannya, ibu mengakses informasi tentang kerumahtanggaan, dan anak-anak dapat bergaul di media sosial sehingga melibatkan dirinya 
Jurnal LINIMASA, Volume 1 Nomor 2, Juli 2018, hlm 1 - 15

sebagai pengguna layanan media sosial tertentu.

Gejala semacam ini sebenarnya sudah dimulai ketika berkembangnya teknologi yang menggunakan media komputer sebagai penyampai pesan. Media ini menampilkan penggambaran yang menimbulkan efek secara tidak sadar pada pola berpikir manusia. Pembangunan yang terjadi di bidang teknologi adalah salah satu dampak dari pemenuhan kebutuhan masyarakat yang terjadi ketika kebutuhan ruang beraktifitas semakin tinggi. Munculnya teknologi-teknologi yang baru menjadi tuntutan zaman melambangkan ruang dinamis dan aktif sebagai pusat beraktifitas atau berkegiatan di era modern sekarang ini.

Pola pikir manusia berubah seiring dengan era infomasi dan mereka menganggap internet sebagai perwujudan citra untuk kepentingan sebuah golongan atau pribadi. Media-media sosial yang terjaring di internet merupakan representasi sebuah makna tersendiri. Mereka menggunakan media internet sebagai media sosialisasi bagi dirinya kepada masyarakat. Ketika pola sosialisasi masyarakat terpusat di internet maka ruang ini momiliki fungsi timbal balik, karena perwujudan citra yang ada di dalamnya merupakan hasil kreasi manusia yang mempunyai nilai ekonomi ketika media ini dikonsumsi oleh masyarakat pengguna gawai (gadget) yang memilih internet sebagai ruang sosialisasi.

Nilai ekonomi dan budaya dari sebuah komoditi yang ditawarkan dalam internet memiliki sifat timbal balik antara produksi, distribusi dan konsumsi serta mereka mendapatkan manfaat dan keuntungan dengan keberadaannya yang diciptakan dari hasil kreasi manusia sendiri. Sistem ini menjadi bagian sistem kapitalis yang memberikan keuntungan pihak-pihak yang menyediakan media sosial. Mediamedia sosial yang bergabung dalam internet memiliki orientasi dan tujuan yang dapat menarik pengguna mereka melalui berbagai macam strategi, khususnya melalui tampilan fisik dalam menyikapi perkembangan komunikasi masyarakat.

\section{Metode Penelitian}

Metode dalam penelitian adalah proses, prinsip dan prosedur yang akan digunakan untuk mendekati problem dan mencari jawaban. Metode digunakan dalam usaha mengamati dan menafsirkan polapola prilaku manusia juga fenomena sfesifik, seperti penelitian kasus (Mulyana, 2008:32).

Dalam penelitian ini, peneliti menggunakan metode penelitian kualitatif yang menunjuk dan menekankan pada proses, dan berarti tidak diteliti sccara ketat atau terukur (jika memang dapat diukur), dilihat dari kualitas, jumlah, intensitas atau frekuensi. Penelitian kualitatif menekankan sifat realita yang dibangun secara sosial, hubungan yang intim antara peneliti dengan yang diteliti dan kendala situasional yang membentuk penyelidikan. Penelitian kualitatif menekan bahwa sifat peneliti itu penuh dengan nilai (value-laden). Mereka mencoba menjawab 
Elly Komala Media Sosial Sebagai...3

pertanyaan yang menekankan bagaimana pengalaman sosial diciptakan dan diberi arti.

Peneliti menekankan pada permasalahan berupa media sosial di internet sebagai sebuah ruang hiperrealitas bagi pengguna layanan untuk bersosialisasi, berinteraksi, menukar informasi, pada layanan media sosial. Peneliti membatasi permasalahan pada media sosial di internet sebagai sebuah ruang hiperrealita pada studi kasus twitter. Obyek penelitian yang peneliti angkat dalam penelitian ini adalah pada media sosial di internet sebagai sebuah ruang hiperrealitas. Dalam konteks penelitian ini, metode kualitatif dirasa paling sesuai karena menekankan sifat realita yang dibangun secara sosial, hubungan yang intim antara peneliti dengan yang diteliti dan kendala situasional yang membentuk peyelidikan. Pengumpulan data yang digunakan dalam penelitian ini adalah (1) Studi kepustakaan (Library Research) adalah teknik pengumpulan data yang dilakukan peneliti dengan mengkaji literaturliteratur, pendapat-pendapat serta pokok-pokok pikiran yang terdapat dalam media cetak khususnya buku-buku dan jurnal elektronik lainnya yang ada hubungannya dengan penyusunan tugas ini. (2) Observasi partisipan yaitu saya mengadakan pengamatan dan penginderaan secara langsung mengenai media sosial di internet sebagai sebuah ruang hiperrealitas pada studi kasus twitter. (3) Wawancara mendalam yaitu pengumpulan data dengan mengajukan pertanyaan secara langsung kepada narasumber/informan.

\section{Pembahasan}

Media Sosial

Pada tahun 1990-an, Mark Poster meluncurkan buku besarnya, The Second Media Age, yang menandai periode baru dimana teknologi interaktif dan komunikasi jaringan, khususnya dunia maya yang akan mengubah masyarakat. Gagasan tentang era media kedua sebenarnya telah dikembangkan sejak tahun 1980an hingga saat ini menandai perubahan penting dalam teori media. Bagi seseorang, hal ini melonggarkan konsep "media" dari komunikasi "massa" hingga berbagai media yang berkisar dari jangkauan yang sangat luas hingga yang sangat pribadi. Kedua, konsep tersebut menarik perhatian peneliti pada bentuk-bentuk penggunaan media yang baru yang dapat berkisar dari informasi individu dan kepemilian pengetahuan hingga interaksi. Ketiga, tesis tentang era media kedua membawa teori media dari kesamaran yang relatif pada tahun 1960-an pada popularitas yang baru pada tahun 1990-an dan seterusnya. Kekuatan media dalam dari media itu sendiri kembali menjadi fokus, termasuk sebuah minat baru dalam karakteristik penyebaran dan penyiaran media.

Era media yang pertama digambarkan oleh (1) sentralisasi produksi (satu menjadi banyak); (2) komunikasi satu arah; (3) kendali situasi, untuk sebagian besar; (4) reproduksi stratifikasi sosial dan perbedaan melalui media; (5) audiens massa yang terpecah; dan (6) pembentukan 
Jurnal LINIMASA, Volume 1 Nomor 2, Juli 2018, hlm 1 - 15

kesadaran sosial. Era media kedua sebaliknya, dapat digambarkan sebagai; (1) desentralisasi; (2) dua arah; (3) di luar kendali situasi; (4) demokratisasi; (5) mengangkat kesadaran individu; dan (6) orientasi individu. (Poster, 1995) Mungkin ada dua pandangan yang dominan tentang perbedaan antara media pertama, dengan penekanannya pada penyiaran, dan era media kedua, dengan penekanannya pada jaringan. Kedua pandangan tersebut adalah pendekatan interaksi sosial (social interaction) dan pendekatan integrasi sosial (social integration).

Pendekatan interaksi sosial membedakan media menurut seberapa dekat media dengan model interaksi tatap muka. Bentuk media penyiaran yang lebih lama dikatakan lebiih menekankan pada penyebaran informasi yang mengurangi peluang adanya interaksi. Media tersebut dianggap sebagai media informasional dan karenanya menjadi mediasi realitas bagi konsumen. Sebaliknya, media baru lebih interaktif dan menciptakan sebuah pemahaman baru tentang komunikasi pribadi.

Merriam-Webster (2013) memberikan definisi media sosial yaitu bentuk komunikasi elektronik (sebagaimana website untuk jaringan sosial dan mikroblog) yang mana pengguna membuat komunitas online untuk berbagi informasi, idea, pesan personal, dan konten lainnya. Media sosial membuat websites mengizinkan pengguna-pengguna untuk berbagi konten, media, dan lain-lain. Contoh umum adalah jaringan sosial yang popular seperti
Friendster, Facebook, Myspace, dan lain-lain. Termasuk juga media sosial Youtube, Photobucket, Flickr, dan situs lain yang ditujukan untuk berbagi foto dan video. Pengumpulan berita dan sumber-sumber referensi online, contohnya Digg dan Wikipedia. Situs mikro blog seperti Twitter juga dapat termasuk sebagai media sosial.

Tentu saja media sosial tidak seperti interaksi tatap muka, tetapi memberikan bentuk interaksi baru yang membawa kita kembali pada hubungan pribadi dalam cara yang tidak bisa dilakukan oleh media sebelumnya. Ada beberapa masalah dalam membuat perbandingan ini, dan beberapa orang yakin bahwa media sosial lebih "termidiasi" daripada yang akan diyakini oleh para pendukungnya. Media baru juga mengandung kekuasaan dan batasan, kerugian dan keuntungan, dan kebimbangan. Sebagai contoh, media sosial mungkin memberikan penggunaan yang terbuka dan fleksibel, tetapi dapat juga menyebabkan kebingungan dan kekacauan. Media sosial memang pilihan yang sangat luas, tetapi pilihan tidak selalu tepat ketika mengingat kebutuhan panduan dan susunan. Perbedaan adalah salah satu nilai besar dalam media sosial, tetapi perbedaan juga dapat menyebabkan adanya perpecahan dan pemisahan. Media sosial mungkin memberikan keluwesan waktu dalam penggunaan, tetapi juga menciptakan tuntutan waktu yang baru. Sebagai contoh, sekarang sudah ada profesi untuk mengecek atau memperbaharui info kekinian di media sosial, dan harus menghabiskan beberapa jam 
sehari hanya untuk mengecek dan memperbaharui hari ini yang tidak menjadi penting 10 tahun yang lalu.

\section{Hiperealitas}

Dunia hiperrealitas merupakan dunia yang sarat oleh silih bergantinya reproduksi objek-objek simulakrum-objekobjek yang murni penampakan, yang tercerabut dari realitas sosial masa lalunya, atau sama sekali tak mempunyai realitas sosial sebagai referensinya. Di dalam dunia seperti ini subjek sebagai konsumer digiring ke dalam pengalaman ruang hyperreal pengalaman silih bergantinya penampakan di dalam ruang, berbaur, dan meleburnya realitas dengan fantasi, fiksi, halusinasi, dan nostalgia, sehingga perbedaan antara satu sama lainnya sulit ditemukan.

Hiperrealitas: Dari medium ke medium, realitas diuapkan, menjadi suatu alegori dari kematian. Realitas juga mempercepat kehancurannya sendiri. Realitas tidak lagi menjadi representasi obyek, melainkan ekstasi pengingkaran dan ritual kebinasaannya sendiri: hiperrealitas...hiperrealitas...men ghapuskan kontradiksi diantara realitas dan khayali. (Baudrillard, 1985)

Bagi Baudrillard (1985) tak ada tempat yang lebih hiperrealistis selain dari padang pasir, dan padang pasir ini adalah Amerika. Ini tentunya, hanya sebuah metafora yang digunakan Baudrillard untuk menerangnkan aspek-aspek halusinasi, khayali, dan fatamorgana yang telah mennguasai kebudayaan Amerika.
Di tengah padang pasir, seseorang dapat menyaksikan citra-citra fatamorgana-citra-citra yang segera menghilang tatkala seseorang mendatangi lebih dekat. Hal yang sama dapat dijumpai tatkala seseorang berada di depan televisi, film tiga dimensi, video, video game dan kini media sosial. Totalitas hidup seseorang (kegembiraan, kesedihan, kesukaan, keberanian, dan sebagainya) - secara tidak sadarterperangkap di dalam dunia hiperealisme media, namun apabila seseorang tersebut mencoba melihat media dengan kesadaran, maka ia akan menyadari bahwa apa yang ia saksikan tak lebih dari sebuah fantasi, fiksi, atau fatamorganasebuah kesemuan.

Menurut Baudrillard (1985), sebelum mencapai kepada tatanan simulasi yang menciptakan hiperrealitas, ada beberapa tahap yang dilalui sebelumnya: counterfeit, production dan simulation. Counterfeit adalah pola yang dominan pada periode klasik, dari renaisans ke revolusi industriimage merupakan representasi dari realitas. Production adalah pola yang dominan dalam era industri-image menutupi realitas. Simulation adalah pola yang merajalela pada tahap sekarang yang dikontrol oleh kode-image menggantikan realitas yang telah sirna, menjadi simulakrum murni. Baudrillard kemudian menambahkan tahapan yang ke empat yang disebut fractal (suatu tahapan trans-everything yang mengubah secara radikal cara pandang kita terhadap dunia). Tatanan-tatanan ini tergambarkan 
Jurnal LINIMASA, Volume 1 Nomor 2, Juli 2018, hlm 1 - 15

dan berhubungan dengan perkembangan zaman jika dilihat dari sejarah peradaban manusia. Setiap perpindahan dari setiap zaman selalu diwarnai sebuah revolusi, yang dalam pemikiran Baudrillard, setiap revolusi menghadirkan tujuan yang sama dalam bentuk yang berbeda, yaitu, imitasi atau reproduksi dari image atau obyek.

Baudrillard (1985) tanpa ragu lagi mengemukakan, bahwa dunia realitas dan dunia hiperealitas media sosial sudah sulit dibedakan-kedua-duanya sama-sama nyata. Media sosial telah berkembang menjadi sebuah realitas kedua. Media sosial telah menjadi dunia nyata kebudayaan, yang menjadi hiburan sebagai ideologinya, sosialisasi sebagai tanda dan perlambang bentuk komoditi, gaya hidup, iklan, sebagai psikologi populernya, dan kosong sebagai perekat yang menyatukan simulakrum para pengguna, citra-citra elektronik sebagai bentuk iktana sosial satusatunya dan paling dinamis, politik media elit sebagai formula ideologisnya, jual beli sosialisasi yang diabstraksikan sebagai medan rasionalisasi pasarnya, sinisme sebagai tanda kebudayaan yang utama dan penycbaran jaringan relasi kekuasaan (power) sebagai produk nyatanya. Media sosial, bahkan lebih nyata dari dunia realitas sendiri, sebab tidak saja realitas yang telah terserap secara total dalam citraan media sosial, tetapi juga karena media sosial mampu membuat penggunannya tenggelamdalam citra simulakrum. Di dalam media sosial, realitas, fantasi, halusinasi, ilusi atau fatamorgana telah melebur menjadi satu.

Sikap skeptis dan fatalis yang dikatakan mewarnai pemikiran-pemikirannya dalam memandang transformasi sosial di dalam era informasi global sekaraang ini, telah memerangkap Baudrillard untuk menyampaikan pandangan-pandanganya secara retoris dan hiperbolis. Namun demikian apapun tuduhan yang dilontarkan, yang jelas adalah, bahwa semangat simulasi dan hiperealitas seperti yang digambarkan Baudrillard ini, diterima atau tidak telah menjalari pelosok-pelosok dunia yang terpencil sekalipun, lewat berbagai medianya, seperti televisi, komputer dan internet.

\section{Counterfeit}

Counterfeit ialah pola keadaan simulacra yang alamiah, menelisik gejala alam, ditemukan pada kesan, gambar, patung, dalam peniruan dan palsu. Hal ini masih dilihat sebagai yang harmonis, optimis, dan yang bertujuan untuk restitusi atau institusi pada alam sebagai image Tuhan. Pada tahap ini sebagai contoh sederhananya ialah lukisan-lukisan yang memakai konsep perspektif. Sebuah konsep yang memanipulasi individu yang melihat lukisan tersebut bahwa lukisan tersebut dapat mendekati kenyataan yang ada.

Zaman feodal adalah zaman yang menggambarkan situasi di mana hubungan dan status sosial masih kaku dan sarat hubungan emosional, dunia symbolic exchange dan seduction. Hidup di dunia masih diterima sebagai sebuah ilusi, dan tidak terdapat masalah dengan realitas 
(Utoyo, 2001). Namun, semenjak memasuki tahap counterfeit hingga simulation, kehadiran tanda tanda semakin dikuatkan sehingga mempengaruhi tatanan sosial. Dalam tahap counterfeit, keberadaan suatu tanda dianggap menjadi sesuatu yang emansipatif dalam tatanan sosial.

\section{Counterfeit dalam Twitter}

Pertama pola counterfeit dalam Twitter; sebagai jejaring sosial, Twitter mengutamakan prinsip pengikut. Jika Anda memilih untuk mengikuti pengguna lain di Twitter, kicauan pengguna akan muncul secara kronologis-terbalik di halaman utama Anda. Jika Anda mengikuti 20 orang, Anda akan melihat berbagai kicauan yang bergulir ke bawah halaman: kicauan sarapan sereal, tautan baru yang menarik, rekomendasi musik, bahkan renungan tentang masa depan pendidikan.

Pandangan peneliti hal ini mengacu pada gagasan bahwa praktik dan estetika bukanlah sesuatu yang langsung ada, tetapi diciptakan atau dibuat. Prinsip pengikut dalam Twitter meniru konsep pengakumulasian dan pengaturan informasi tentang semua orang, objek, situasi dan gagasan yang membentuk sikap atau kecenderungan untuk bertindak dengan cara yang positif atau negatif terhadap objek. Pola penggabungan informasi ini adalah satu kekuatan yang berpotensi untuk memengaruhi sebuah sistem kepercayaan atau sikap individu. Prinsip penggabungan informasi ini ditiru polanya oleh "pengikut" atau "follow" a'la Twitter.
Kedua, pengguna bisa berlangganan kicauan pengguna lain dengan cara mengikuti (follow) pengguna yang bersangkutan, dan pengguna yang mengikuti tersebut akan menjadi pengikut (followers) bagi pengguna yang diikutinya. Sebutan lainnya adalah tweeps, singkatan dari Twitter dan peeps. Pengguna bisa memeriksa orangorang yang membatalkan pertemanan (unfollowing) melalui berbagai layanan. Selain itu, pengguna juga bisa memblokir pengguna lain yang telah mengikuti mereka.

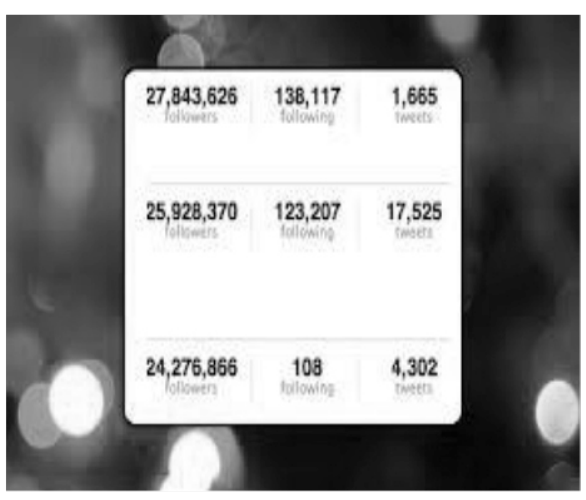

\section{Gambar 1}

Pemberitahuan followers, following, dan tweets dalam Twitter

Pada tahap berkembang, kemungkinan elaborasi dalam komunikasi menjadi hal yang secara subtansi ditirukan di "follow" a'la Twitter. Kemungkinan ini mencoba untuk memprediksi kapan serta bagaimana individu "akan" dan "tidak akan" terbujuk oleh kicauan pengguna lainnya. Hal ini mencoba untuk menjelaskan 
Jurnal LINIMASA, Volume 1 Nomor 2, Juli 2018, hlm 1 - 15

dengan cara yang berbeda di mana individu akan mengevaluasi informasi yang diterima. Terkadang, individu mengevaluasi pesan dalam cara yang rumit, menggunakan pemikiran yang kritis, dan kadang-kadang individu melakukannya dengan cara yang lebih sederhana dan dengan cara yang kurang kritis. Yang jelas ialah hal kemungkinan elaborasi ini dikodekan melalui "follow" dan "unfollow".

Ketiga, pengguna dapat mengelompokkan kicauan menurut topik atau jenis dengan menggunakantagar (hashtag) kata atau frasa yang diawali dengan tanda "\#". Sedangkan tanda "@", yang diikuti dengan nama pengguna, digunakan untuk mengirim atau membalas kicauan pada pengguna lain. Untuk memosting ulang kicauan pengguna lain dan membaginya pada pengikut sendiri, terdapat fitur retweet, yang dilambangkan dengan "RT". Pada akhir 2009, Twitter menambahkan fitur "daftar" (list), yang memungkinkan pengguna untuk mengirim dan membalas kicauan pada daftar pengguna, bukannya pada pengguna secara perorangan.

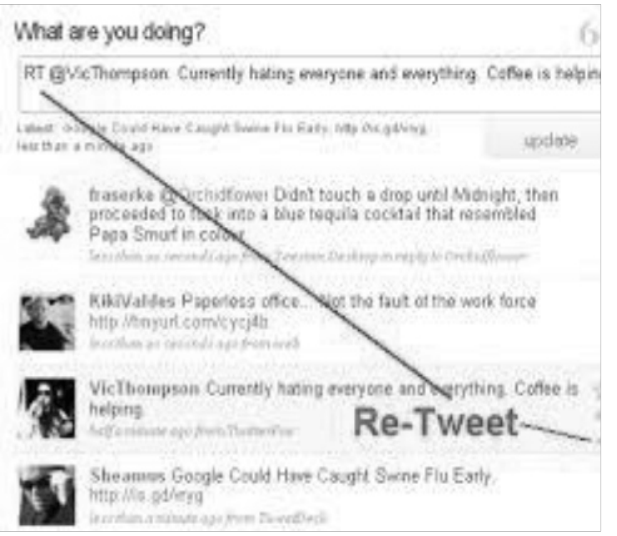

Gambar 2 re-tweet menggunakan simbol "RT" dalam Twitter

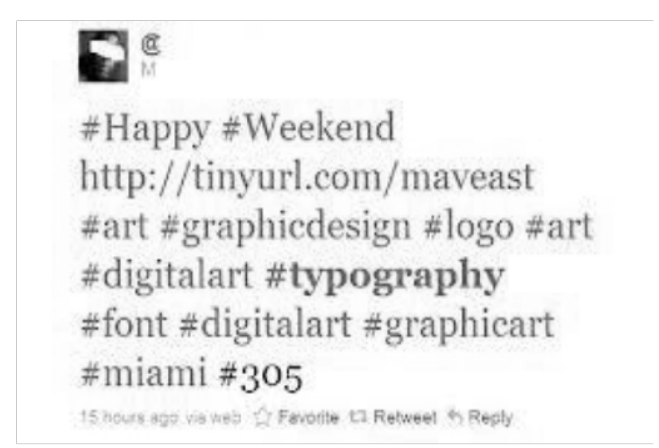

Gambar 3

Pengelompokan topik kicauan melalui simbol "\#” dalam Twitter

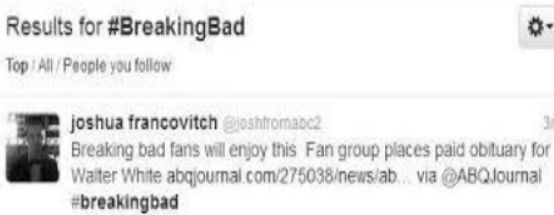

\section{Gambar 4}

Kicauan yang menggunakan simbol "\#” dalam Twitter

Penggunaan sistem yang mendasari hal ini ialah logika konvensional yang mana memandang komunikasi sebagai sebuah permainan yang dimainkan dengan peraturan "hastag", “@”, "RT", dan "daftar". Di sini, komunikasi adalah sebuah cara pengungkapan diri yang berjalan sesuai aturan-aturan, normanorma yang diterima, termasuk hak dan kewajiban setiap orang yang terlibat. Logika ini bertujuan untuk menyusun pesan-pesan yang didasarkan pada aturan-aturan Twitter. 


\section{Production (produksi)}

Produksi ialah keadaan

simulacra yang produktif, sehingga penampakannya sebagai sesuatu yang didasarkan pada fenomena produksi, ditemukan dalam bidang energi, kekuatan, materialisasi oleh mesin dan dalam keseluruhan sistem produksi. Sebuah maksud kelanjutan globalisasi dan ekspansi, dari sebuah pembebasan energi yang tidak terbatas (termasuk hasrat untuk menghubungkan impian dalam fase simulacra ini). Sebuah desain yang tercipta ditujukan untuk diciptakan menjadi sesuatu yang real.

Keadaan tatanan nilai berlanjut kepada sebuah pasar nilai, dimana sebuah nilai bukan sekedar menjadi simbol atas realita yang sudah ada. Pada tahap ini nilai-nilai tersebut dapat dipertukarkan layaknya kondisi pasar. Contoh sederhana dari kondisi ini adalah nilai tukar valuta asing yang saling diperjualbelikan tetapi tidak meninggalkan nilai dari uang tersebut dimana uang merupakan simbolisasi dari nilai barang real. Era tersebut dapat dikatakan masuk ke dalam era produksi. Dalam sejarah peradaban manusia, cra terscbut dimulai sejak tahap industrial, setelah tahap renaissance.

Era revolusi industri di Inggris menciptakan produksi massal bagi sebuah produk karena pabrik-pabrik bermunculan. Perkembangan teknologi yang sangat pesat: kereta api, telepon, telegraf, motion pictures, dan mesin ketik membuat komunikasi semakin tersebar luas. Teknologi yang berkembang pada saat itu memberi peluang bagi kreatifitas untuk membuat komunikasi menjadi semakin variatif.

\section{Produksi Dalam Twitter}

Twitter adalah layanan jejaring sosial dan mikroblog daring yang memungkinkan penggunanya untuk mengirim dan membaca pesan berbasis teks hingga 140 karakter, yang dikenal dengan sebutan kicauan (tweet). Twitter didirikan pada bulan Maret 2006 oleh Jack Dorsey, dan situs jejaring sosialnya diluncurkan pada bulan Juli. Sejak diluncurkan, Twitter telah menjadi salah satu dari sepuluh situs yang paling sering dikunjungi di internet.

Dengan semakin diproduksi massal layanan Twitter dan semakin banyak orang yang menggunakan Twitter maka semakin banyak juga media promosi bagi Twitter. Dengan "stimulus" tersebut pengguna akan terperangkap di dalam "Godaan" atau Seduction.

Twitter itu jaringan yang lebih praktis akses dan mudah, alur informasi

cepat dalam

hitungan detik

informasinya

berbeda-beda.

Akses mencari

teman dan ajang

eksistensi dan

gengsi.

(wawancara

dengan $R$ mengenai

alasan

menggunakan

Twitler)

Biar tau seberapa

banyak yang

kepoin (pengen 
Jurnal LINIMASA, Volume 1 Nomor 2, Juli 2018, hlm 1 - 15

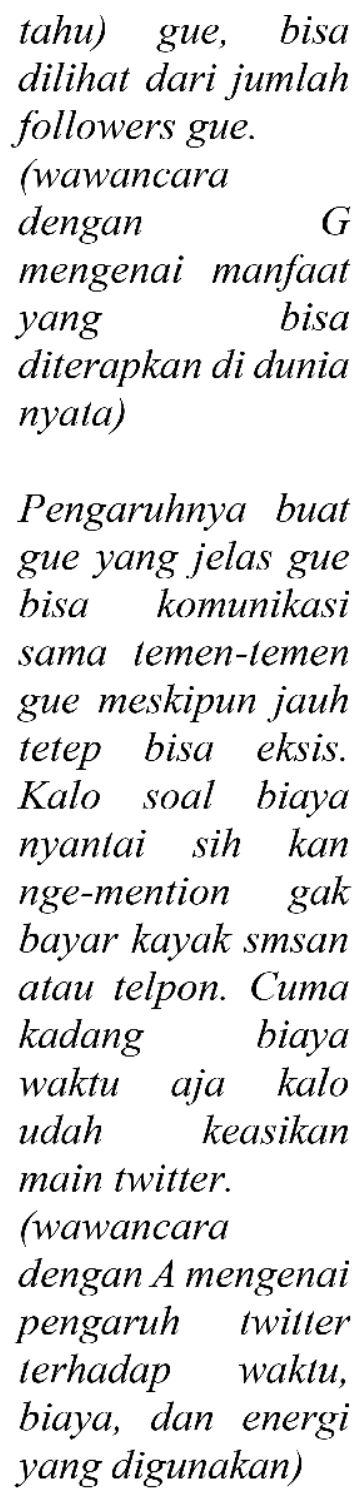

Menurut Wolfgang Sigogo Xemandros, Membeli komoditas adalah aktivitas yang sudah dirckayasa scbclumnya yang terjadi pada persilangan dua sistem: Yaitu individual, yang bersifat cair, tidak saling berhubungan dengan sesamanya, dan relasi produksi, yang dikodifikasi, berlanjut dan merupakan kesatuan. Tidak ada interaksi di antara keduanya, melainkan integrasi yang dipaksakan dari sistem kebutuhan kepada sistem produksi.
Sebagai sebuah sistem, kebutuhan sangat berbeda dengan kesenangan dan pemuasan yang diciptakan sebagai bagian dari sistem dan bukan dalam kerangka hubungan antara individu dengan objek. Sistem kebutuhan adalah produk sistem produksi. Jadi, kebutuhan diciptakan sebagai kekuasaan konsumsi.

\section{Simulation (simulasi)}

Simulacra dari simulasi. Simulasi adalah pola keadaan simulacra yang ditemukan dalam informasi, model, cyber, perencanaan total, dengan tujuan kontrol penuh. Menurut Baudrillard pada kondisi sekarang yang-nyata yang telah menjadi alibi dari model, di dunia yang dikendalikan oleh prinsip simulasi. Dan, secara paradoks, yang-nyata yang telah menjadi Utopia kita yang sejati - tetapi Utopia yang tidak lagi pada domain kemungkinan, yang hanya dapat diimpikan sebagai satu mimpi yang kehilangan objeknya.

Tahapan yang ketiga, simulasi terjadi pada zaman sekarang di mana segala sesuatunya disimulasi, dengan hukum yang berlaku adalah hukum struktural nilai. Dalam tahap ini tanda-tanda benar-benar tcrpisah dari realitas yang ada dan menciptakan sistem sendiri sehingga dapat dipermainkan tanpa harus kehilangan jati diri dari counterfeit itu sendiri terhadap tatanan sosial: Dalam tatanan di mana kita hidup sekarang ini sebenarnya counterfeit tetap hidup dalam bentuk substansial atau bentuk dasarnya. Akan tetapi counterfeit tidak lagi mempengaruhi relasi dan struktur masyarakat. Yang 
berlaku di dunia sekarang ini adalah kode.

Dengan aktifnya sebuah kode (dan metafisika kode), segala hal di dunia ini dapat bergerak secara terlepas dari dunia nyata. Era simulasi pun sudah dimulai dan terjadi. Referensi dilikuidasi dan representasi tidak dapat ditemukan lagi dalam setiap objek. Ketika masyarakat memercayakan sesuatu yang pada hakikatnya bukan apa-apa dan bahkan belum terjadi, tetapi karena adanya prediksi yang mendekati kenyataan, maka saat itulah realitas menjadi tidak berdiri pada definisinya. Simulasi dan realitas tidak terbedakan lagi. Inilah yang disebut sebagai hiperrealitas. Suatu kondisi di mana kita tidak bisa lagi membedakan mana yang origin dan mana yang ekstensi; mana yang asli dan mana yang salinan; mana yang primer dan mana yang sekunder. Ini jelas sebuah kondisi brutal dari tandatanda.

\section{Simulasi Dalam Twitter}

Twitter adalah layanan jejaring sosial dan mikroblog daring yang memungkinkan penggunanya untuk mengirim dan membaca pesan berbasis teks hingga 140 karakter, yang dikenal dengan sebutan kicauan (tweet). Twitter didirikan pada bulan Maret 2006 oleh Jack Dorsey, dan situs jejaring sosialnya diluncurkan pada bulan Juli. Sejak diluncurkan, Twitter telah menjadi salah satu dari sepuluh situs yang paling sering dikunjungi diInternet, dan dijuluki dengan "pesan singkat dari Internet." Di Twitter, pengguna tak terdaftar hanya bisa membaca kicauan, sedangkan pengguna terdaftar bisa memosting kicauan melalui antarmuka situs web, pesan singkat (SMS), atau melalui berbagai aplikasi untuk perangkat seluler. Media sebagai cara membangun budaya, menempatkan lebih banyak penekanan pada pemikiran ketimbang pada materi. Ketika pengguna internet itu menyalakan jaringannya, kicauan di Twitter bisa membacanya, simbol, nilai, dan keyakinan mereka bergema dalam pikiran pengguna tak terdaftar.

Tingginya popularitas Twitter menyebabkan layanan ini telah dimanfaatkan untuk berbagai keperluan dalam berbagai aspek, misalnya sebagai sarana protes, kampanye politik, sarana pembelajaran, dan sebagai media komunikasi darurat. Twitter juga dihadapkan pada berbagai masalah dan kontroversi seperti masalah keamanan dan privasi pengguna, gugatan hukum, dan penyensoran. Twitter dimiliki dan dioperasikan oleh Twitter, Inc., yang berbasis di San Francisco, dengan kantor dan server tambahan terdapat di New York City, Boston, dan San Antonio.

Dalam upacara pembukaan Olimpiade Musim Panas 2012, bertempat di Stadion Olimpiade, Sir Tim Berners-Lee, penemu World Wide Web, memosting kicauan: "This is for everyone", yang dipantulkan melalui sebuah lampu LCD ke 80.000 orang di kursi penonton. Menurut analisa akun, 125 kepala negara dan 139 politisi terkemuka di dunia mempunyai akun Twitter yang jika digabungkan memiliki kicauan lebih dari 350.000 dan hampir 52 juta pengikut. Namun, hanya 30 
Jurnal LINIMASA, Volume 1 Nomor 2, Juli 2018, hlm 1 - 15

akun yang menulis kicauan mereka sendiri, lebih dari 80 akun tidak mengikuti politisi lainnya dan sebagian besarnya bahkan tidak mengikuti siapapun.

tagar $\begin{array}{cr}\text { Media menduga bahwa } \\ \text { \#wikileaks }\end{array}$ \#occupywallstreet disensor oleh Twitter karena topik ini tidak muncul dalam daftar tren. Twitter menanggapinya dengan menyatakan bahwa "kami tidak menyensor tagar kecuali mengandung kata-kata kotor. "Lebih dari dua puluh kardinal Katolik Roma memiliki akun Twitter yang aktif, sembilan di antaranya adalah kardinal elektor dalam Konklaf Kepausan 2013. Twitter juga menyebabkan penggunaan TV menjadi lebih interaktif. Efek ini terkadang disebut dengan "pendingin air virtual" atau "televisi sosial". Twitter berhasil mendorong orangorang agar menyaksikan acara siaran langsung televisi, seperti Oscars, Super Bowl, dan MTV Video Music Awards; namun strategi ini kurang efektif pada acara-acara TV terjadwal. Pada April 2013, akun Associated Press diretas, melaporkan bahwa Presiden AS Barack Obama terluka dalam sebuah serangan di Gedung Putih. Saham perusahaan ini merosot seketika \$134 juta, dan nilainya kembali ke semula setelah diketahui bahwa laporan tersebut palsu.

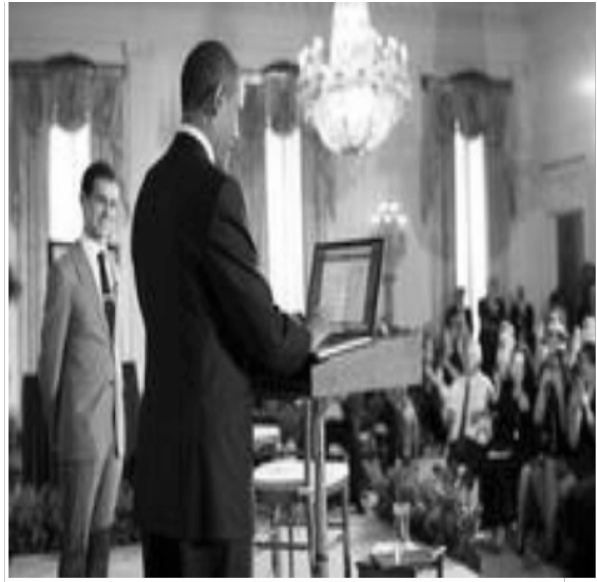

Gambar 5

Dorsey (kiri) berkata bahwa setelah "Twitter Town Hall with

Barack Obama" digelar pada bulan Juni 2011, Twitter menerima lebih dari 110.000 kicauan dengan tagar \#AskObama

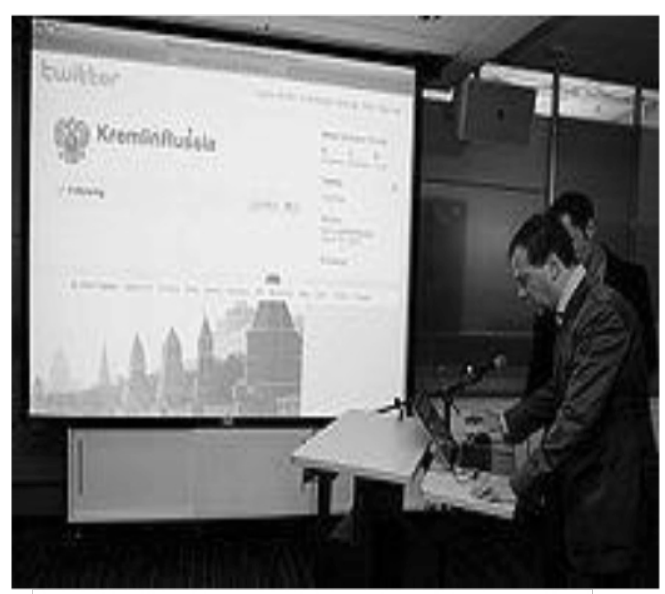

\section{Gambar 6}

Presiden Rusia Dmitry Medvedev membuka akun Twitternya di kantor Twitter pada tanggal 23 Juni 2010; sumber Wikipedia.org

Dari berbagai contoh masa lalu di atas dapat peneliti mengambil bahwa pola simulasi berhasil menjadikan ekspresi yang sepenuhnya sebagai narasi menjunjung tinggi kesuksesan Twitter. Dampak luar biasa yang beragam dalam berbagai aspek 
Elly Komala Media Sosial Sebagai...13

kehidupan - diproduksi atau pun reproduksi hiperealitas - manusia harus bertinggkah laku sesuai dengan kategori kekinian. Hal ini disebabkan perhatian produsen, dalam hal ini produsen twitter, lebih ditujukan pada teknik reproduksi, bukan pada kandungan estetik namun tak lebih dari pola simulasi.

Dalam pola simulasi Twitter putusnya rantai petandaan yang membentuk satu ungkapan atau makna menghasilkan ungkapan partisiasi-bahkan sampai pada dinamika politikpetinggi politik sebagai efek yang ditumbulkan. Oleh sebab itulah, seorang Barrack Obama, Dmitry Medvedev dan lainnya mengenali akun Twitter untuk merepresentasikan dirinya, peneliti beranggapan sebabnya bahwa ia menganggap penanda itu yang representatif untuknya sekaligus menjadi referensi untuk aktifitas politiknya. Dalam iklim kontemporer, menurut Heidegger sampai pada satu zaman, yang di dalamnya eksistensi manusia tak lebih dari suatu citraan.

\section{Kesimpulan}

Berdasarkan hasil penelitian dan analisis yang telah peneliti lakukan mengenai media sosial sebagai sebuah ruang hiperalitas, maka dapat ditarik beberapa kesimpulan yang dapat bermanfaat dalam menggunakan layanan media sosial pada umumnya termasuk Twitter pada khususnya. Adapun kesimpulan yang dapat ditarik oleh peneliti dalam penelitian ini adalah (1) Pola counterfeit atau keadaan simulacra alamiah dari hubungan dunia nyata dengan ditandai berbagai aplikasi dunia maya dalam Twitter. (2) Pola production atau keadaan simulacra produktif yang menciptakan produksi massal bagi sebuah produk yang dapat dikonsumsi hingga menguasai kawasan global yaitu layanan Twitter itu sendiri. (3) Pola simulation adalah pola keadaan simulacra yang ditemukan dalam informasi, model, cyber, perencanaan total, dengan tujuan kontrol penuh. Pesan-pesan media sosial Twitter dipenuhi oleh gambar-gambar simbolis yang memang dirancang untuk mempengaruhi individu dan masyarakat. Secara keseluruhan Twitter telah memenuhi unsurunsur sebagai sebuah ruang hiperealitas menurut teori hiperealitas Baudrilard.

\section{Daftar Pustaka}

Aziz,M.I. 2001. Galaksi Simulacra Jean Baudrillard. Yogyakarta: Lkis.

Azwar, M. 2014. Teori Simulakrum Jean Baudrillard dan upaya pustakawan mengidentifikasi informasi realitas. Jurnal Ilmu Perpustakaan \& Kearsipan Khizanah AlHikmah, Vol.2 No. 1, hlm. 38-48

Baudrilard, Jean. 1981. For a Critique of Political Economy of The Sign. USA: Telos Press. 
Jurnal LINIMASA, Volume 1 Nomor 2, Juli 2018, hlm 1 - 15

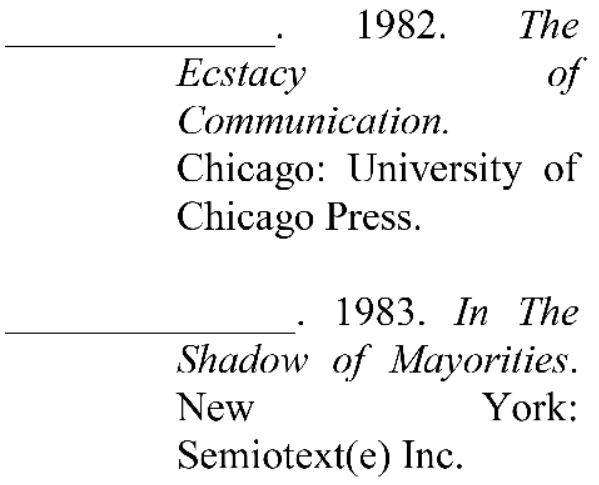

1984.

Simulacra and

Simulation. Michigan:

University of Michigan

Press.

1998.

Consumer Society, Myth and Structures. London : SAGE Publications Ltd.

Brigg Asa \& Burke Peter. 2006. SEJARAH SOSIAL MEDIA: Dari Gutenberg sampai Internet. (Zainudin, A. Rahman, Trans.). Jakarta: Yayasan Obor.

Bungin, H. M Burhan. 2006. Metode Penelitian Kualitatif. Jakarta: Rajawali Pers.

2006. Sosiologi Komunikasi : Teori, Paradigma, dan Diskursus Teknologi Komunikasi di Masyarakat. Jakarta: Kencana Prenada Media Group.

Demartoto, Argyo. 2009. Membedah Gagasan
Post Modernisme Baudrillard : Realitas Semu. Jurnal Sosiologi DILEMA $21: 12-20$

Eco, Umberto. 1987. Tamasya Dalam Hiperealitas (terj.), Jakarta: Jalasutra.

Heidegger, Martin. 1995. Being and Time. Oxford: Basil Blackwell.

Moleong, Lexy. 2000. Metodologi Penelitian Kualitatif. Bandung: PT Remaja Rosdakarya.

Mulyana, Deddy. 2000. Ilmu Komunikasi Suatu Pengantar. Bandung: PT Remaja Rosdakarya. 2001. Metode

Penelitian Kualitatif. Bandung : PT Remaja Rosdakarya 2008. Metode Penelitian Komunikasi, Edisi Revisi. Bandung: PT Remaja Rosdakarya

Piliang, Yasraf Amir. 1999. Hiper Realitas Kebudayaan. Yogyakarta: LKIS.

Poster, Mark. 1995. The Second Media Age. Cambridge. UK: Polity Press.

Sugiyono. 2007. Metode Penelitian Kuantitatif, Kualitatif $R \& D$. Bandung: Alfabeta.

Xemandros, Wolfgang Sigogo. 2010. Hiperrealitas 
Elly Komala Media Sosial Sebagai...15

dalam iklan menurut pemikiran Jean

Baudrillard. Filsafat FIB UI Depok.

Sumber lain:

Merriam-webster 1816. https://www.merriamwebster.com/dictionary/ social $\% 20$ media diakses februari 2018

http://www.romelteamedia.com/2 014/04/media-sosial-pengertian karakteristik.html diakses februari 2018 